\title{
Methacholine and PDGF activate store-operated calcium entry in neuronal precursor cells via distinct calcium entry channels
}

\author{
PAUL CUDDON ${ }^{1,2}$, MARTIN D BOOTMAN $^{1,3}$, GILLIAN R RICHARDS $^{2}$, \\ ALISON J SMITH ${ }^{2}$, PETER B SIMPSON ${ }^{2,4}$ and H LLEWELYN RODERICK ${ }^{1,4,5}$
}

\footnotetext{
${ }^{1}$ Laboratory of Molecular Signalling, Babraham Research Campus, Babraham, Cambridge, CB2 4AT, UK

${ }^{2}$ Neuroscience Research Centre, Merck Sharp \& Dohme, Terlings Park, Harlow, Essex, CM20 2QR, UK.

3 To whom correspondence should be addressed: martin.bootman@bbsrc.ac.uk

4 These authors contributed equally to this work.

${ }^{5}$ Department of Pharmacology, University of Cambridge, Cambridge, UK. CB2 1PD.
}

\begin{abstract}
Neurons are a diverse cell type exhibiting hugely different morphologies and neurotransmitter specifications. Their distinctive phenotypes are established during differentiation from pluripotent precursor cells. The signalling pathways that specify the lineage down which neuronal precursor cells differentiate remain to be fully elucidated. Among the many signals that impinge on the differentiation of neuronal cells, cytosolic calcium $\left(\mathrm{Ca}^{2+}\right)$ has an important role. However, little is known about the nature of the $\mathrm{Ca}^{2+}$ signals involved in fate choice in neuronal precursor cells, or their sources. In this study, we show that activation of either muscarinic or platelet-derived growth factor (PDGF) receptors induces a biphasic increase in cytosolic $\mathrm{Ca}^{2+}$ that consists of release from intracellular stores followed by sustained entry across the plasma membrane. For both agonists, the prolonged $\mathrm{Ca}^{2+}$ entry occurred via a store-operated pathway that was pharmacologically indistinguishable from $\mathrm{Ca}^{2+}$ entry initiated by thapsigargin. However, muscarinic receptor-activated $\mathrm{Ca}^{2+}$ entry was inhibited by siRNA-mediated knockdown of TRPC6, whereas $\mathrm{Ca}^{2+}$ entry evoked by PDGF was not. These data provide evidence for agonist-specific activation of molecularly distinct store-operated $\mathrm{Ca}^{2+}$ entry $^{2}$ pathways, and raise the possibility of privileged communication between these $\mathrm{Ca}^{2+}$ entry pathways and downstream processes.
\end{abstract}

Key terms: $\mathrm{Ca}^{2+}$, PDGF, methacholine, TRPC6, SOCE, human neurosphere-derived cells

\section{INTRODUCTION}

The cells required for brain development and growth are generated through the proliferation and differentiation of a population of neuronal stem cells (Reynolds and Weiss, 1992). As well as being present in the developing brain, stem cells have recently been identified in several regions of the adult brain (AlvarezBuylla and Temple, 1998; Cameron and McKay, 1998; Gage, 1998). Such neuronal stem cells may be responsible for the replacement of dying or damaged neurons
(Armstrong and Svendsen, 2000; Gage, 1998; McKay, 2000; Reynolds and Weiss, 1992). These neuronal stem cells can be isolated and maintained in culture, and given the right cues they can differentiate into all the major cell types of the brain: astrocytes, oligodendrocytes and neurons (Gage, 1998; McKay, 2000; Svendsen et al., 1998). In addition, in vitro application of mitogens, such as epidermal growth factor, PDGF and fibroblast growth factor, cause these stem cells to self-renew, to form a three-dimensional structure called a neurosphere from which neuronal cells can cells 
be obtained and studied (Caldwell et al., 2001; Doetsch et al., 2002).

Stem cells and their more committed daughter cells (neural precursor cells) have been cited as a possible source of tissue to replace dead, dying or damaged neurons in patients suffering from particular neurodegenerative disorders (Gage, 1998; McKay, 2000). For example, embryonic ventral mesencephalon cells have been successfully transplanted into the striatum of patients suffering from Parkinson's disease, producing a lasting symptomatic improvement (Dunnett et al., 2001). However, these primary cells are not readily available, whereas human neurospherederived cells (NDCs) can be expanded in vitro after dissection (Svendsen et al., 2001; Svendsen et al., 1998). NDCs therefore potentially represent an alternative source of neuronal cells without the ethical concerns associated with embryonic stem cells. Disappointingly, however, these cells have yet to show the same migration, differentiation and integration potential as their totipotent embryonic counterparts (Caldwell et al., 2001).

To provide insight into the mechanisms that control NDC fate, research has focussed on understanding the environmental factors and signalling pathways that control their proliferation and differentiation. It is apparent that diffusible factors within the developing brain create specific microenvironments that through defined signalling pathways direct stem cell fate choices (Spradling et al., 2001). These include growth factors, neurotrophins, cytokines, or more general neurotransmitters, such as those that are released by astrocytes at the site of brain injury (Ridet et al., 1997). It is likely that identification of the environmental cues and signalling pathways that specify the lineage down which neuronal precursor cells differentiate will have considerable clinical benefit (Armstrong and Svendsen, 2000).

Stimulation of neural stem cells with a range of physiological agonists, including neurotransmitters, such as acetylcholine, or growth factors including PDGF, promotes neural stem cell proliferation and/or differentiation (Erlandsson et al., 2001; Ma et al., 2000). Common to all of these agonists is the engagement of the phospholipase C (PLC) signalling cascade (Clapham, 1995). Upon activation, PLC cleaves phosphatidylinositol 4,5bisphosphate into diacylglycerol (DAG) and inositol 1,4,5-trisphosphate $\left(\mathrm{InsP}_{3}\right)$. DAG remains in the plane of the membrane, whereas $\mathrm{InsP}_{3}$ is water-soluble and diffuses through the cytosol to find its cognate receptor on the ER and stimulates $\mathrm{Ca}^{2+}$ release (Berridge et al., 2003). To replenish the depleted ER $\mathrm{Ca}^{2+}$ store, a plasma membrane $\mathrm{Ca}^{2+}$ influx pathway known as store-operated $\mathrm{Ca}^{2+}$ entry (SOCE) is activated (Parekh and Putney, 2005; Putney, 1986). In addition to activating SOCE, other downstream products of PLC activation, including DAG and arachidonic acid, have been demonstrated to stimulate non-store operated $\mathrm{Ca}^{2+}$ entry (Chyb et al., 1999; Moneer and Taylor, 2002; Peppiatt et al., 2004; Shuttleworth and Thompson, 1999). $\mathrm{Ca}^{2+}$ influx arising from these entry pathways serves to prolong the duration of the agonist-induced $\mathrm{Ca}^{2+}$ signals with longterm consequences for cell function (Parekh and Putney, 2005).

It is well established that $\mathrm{Ca}^{2+}$ signals are central to neuronal physiology, controlling development, migration, synaptic transmission and memory consolidation (Berridge, 1998; Spitzer, 2002). Through regulation of the amplitude, frequency and location of $\mathrm{Ca}^{2+}$ signals, extracellular stimuli can specifically regulate diverse cellular functions (Berridge, 1997). In particular, hormones that signal through G-protein coupled receptors are known to evoke responses in fully differentiated neurons, and control many aspects of brain function. For example, the stimulation of muscarinic acetylcholine receptors has been linked to the modulation of synaptic plasticity (Yamamoto et al., 2002), in addition to the regulation of cholinergic and dopaminergic neurotransmission (Delmas et al., 2002; Lezcano and Bergson, 2002) and also the regulation of gene expression (Caulfield, 1993; Ma et al., 2000; Simpson et al., 1994; Zhao et al., 2003). Moreover, muscarinic receptors expressed by neural precursors transduce a growth-regulatory signal during neurogenesis via signalling pathways that 
are known to evoke $\mathrm{Ca}^{2+}$ changes (Ma et al., 2000). Based on these observations, we set out to characterise the profile of the cellular $\mathrm{Ca}^{2+}$ signals generated following cellular stimulation by muscarinic receptor activation in NDCs, and compared them to the $\mathrm{Ca}^{2+}$ increases caused by the established mitogen PDGF.

\section{METHODS}

\section{Neurosphere Culture}

Human neural precursors (Clonetics", Cambrex, East Rutherford, NJ) were grown as neurospheres in Dulbecco's Modified Eagle's Medium (DMEM; Sigma-Aldrich, Poole, UK) /F12 (Invitrogen Life Technologies, Paisley, UK) 3:1; N2, $1 \%$ (Invitrogen Life Technologies); EGF, 20 $\mathrm{ng} / \mathrm{ml}$ (Peprotech, London, UK) and LIF, 10 $\mathrm{ng} / \mathrm{ml}$ (Chemicon, Hampshire, UK), as previously described (Richards et al., 2004; Richards et al., 2006). Neurospheres were passaged every two weeks by chopping into $250 \mu \mathrm{m}$ cubes using a tissue chopper (Mickle Laboratory Engineering, Guildford, UK). Cells were prepared for plating 7-12 days post-chopping following dissociation with Accutase ${ }^{\mathrm{TM}}$ (1:5 HBSS, Innovative Cell Technologies, San Diego, CA). Briefly, neurospheres were washed three times in phosphate-buffered saline (PBS, Sigma-Aldrich), followed by the addition of $3 \mathrm{ml}$ Accutase in HBSS (Invitrogen Life Technologies) and left on a shaker for 30 minutes at $37^{\circ} \mathrm{C}$. After addition of PBS, cells were dissociated by trituration with a $10 \mathrm{ml}$ pipette. Cells were harvested by centrifugation at $150 \mathrm{~g}$ for 5 minutes, and resuspended in standard plating medium (DMEM/F12, 3:1; transferrin, $50 \mu \mathrm{g} / \mathrm{ml}$ Merck Biosciences); insulin, $5 \mu \mathrm{g} / \mathrm{ml}$; progesterone, $20 \mathrm{nM}$; putrescine, $100 \mu \mathrm{M}$; T3, $30 \mathrm{nM}$; selenium, $30 \mathrm{nM}$ (all from Sigma-Aldrich) with further trituration. For microplate-based experiments, cells were plated at 21,000 cells per well in 96-well black-sided microtitre poly-D-lysine coated plates (Biocoat ${ }^{\mathrm{TM}}$, BD Biosciences, Oxford, UK) that had also been coated with laminin (1 $\mu \mathrm{g} / \mathrm{ml}$ (Sigma).

\section{Cell-based Microplate $\mathrm{Ca}^{2+}$ Imaging}

Cells were washed with Krebs/Hanks Buffer (KHB) three times and incubated with $5 \mu \mathrm{M}$ Fluo-3-AM/0.004\% pluronic acid (Molecular Probes) for 1 hour at room temperature. Following incubation, cells were washed 3 times in KHB, and transferred to a $\mathrm{BD}^{\mathrm{TM}}$ Pathway $\mathrm{HT}$ (BD Biosciences) plate imager for compound addition and image collection (Chan et al., 2005). Data was analysed using an in-house custom data analysis package to express data as change in fluorescence over basal or $\Delta \mathrm{F} / \mathrm{F}_{0}$.

\section{ImmunoBlotting}

NDCs were washed and scraped into icecold PBS. Cell suspensions were centrifuged at 1,000 rpm for 5 mins. Cells were lysed by incubation for $1 \mathrm{hr}$ on ice in buffer containing: $10 \mathrm{mM}$ Tris- $\mathrm{HCl}(\mathrm{pH}$ 7.6), $140 \mathrm{mM} \mathrm{NaCl}, 1 \%$ Triton $\mathrm{X}-100,5$ $\mathrm{mM} \mathrm{NaF}, 1 \mathrm{mM} \mathrm{NaPP}$, $0.02 \mathrm{mM}$ leupeptin, $0.2 \mathrm{mM}$ 4-(2-Aminoethyl)benzenesulfonyl fluoride (AEBSF), as described previously (Kasri et al., 2004). Proteins were resolved by SDS-PAGE (10\%) and electroblotted onto $0.2 \mu \mathrm{m}$ nitrocellulose membranes. The membranes were incubated in blocking buffer (Tris-buffered saline (TBS) containing $0.1 \%$ Tween-20 (v/v) and 5\% skimmed milk (w/v)) for 1 hour at room temperature, followed by overnight incubation at $4{ }^{\circ} \mathrm{C}$ in the same buffer containing mouse anti-hTRPC6 (1:500; Alomone) or anti-beta actin $(1: 10,000$; Sigma). Immunoreactive proteins were detected using horse radish peroxidase(HRP-) conjugated anti-mouse IgG (1:10,000, Jackson Immunoresearch) and visualised with a chemiluminescent substrate for HRP (ECL, Pierce Chemicals).

\section{siRNA Transfection of NDCs}

Reduction in hTRPC6 expression was achieved by RNA interference (siRNA, Elbashir et al., 2001a; Elbashir et al., 2001b). SmartPool siRNAs consisting of four different siRNA oligonucleotides targeted against hTRPC6 were obtained from 
Dharmacon. Efficient silencing was assessed by immunoblotting and immunofluorescence, using a primary antibody directed against hTRPC6 (Alamone). 0.1 ug siRNA duplex was transfected using JetSI (QBiogene) per well of a 96 well plate for imaging and immunofluorescence according to manufacturers instructions. $1 \mu \mathrm{g}$ siRNA was used per well of a 6 well plate for Western blotting whit inmunoblotting.

\section{Statistics}

Statistical analysis of data was performed using Student's $t$-test in the case of two samples or One-Way ANOVA using Tukey's Multiple Comparison test for three or more samples. All experiments represent an average of 3 or more experiments, each using multiple wells of a 96 well plate, unless otherwise specified. In all experiments involving the ArrayScanII, multiple fields were recorded within each well this last sentencer. Statistical significance is denoted by: $* * \mathrm{p}<0.01$, $* * * \mathrm{p}<0.001$.

\section{RESULTS}

\section{PDGF and $\mathrm{MCH}$ evoked biphasic $\mathrm{Ca}^{2+}$ responses}

To explore the notion of $\mathrm{Ca}^{2+}$ as a signal downstream of G-protein-coupled receptors and growth factor receptors in NDCs, we compared the kinetics and profiles of the $\mathrm{Ca}^{2+}$ responses induced by a range of concentrations of $\mathrm{MCH}$ and PDGF (Fig. 1). Representative traces showing the response of the cells to $0.3,3$ and $30 \mathrm{ng} / \mathrm{ml} \mathrm{PDGF}$ and $0.1,10$ and $100 \mu \mathrm{M} \mathrm{MCH}$ are shown in figure $1 \mathrm{~A}$. It is evident that both agonists evoked increases in cytosolic $\mathrm{Ca}^{2+}$ that comprised of a rapid rise, which typically reached a distinct peak, followed by a prolonged elevation in intracellular $\mathrm{Ca}^{2+}$ that persisted for the duration of stimulation. Extended dose response curves indicated that application of $\mathrm{MCH}$ or PDGF caused concentration-dependent effects. The peak amplitude (data not shown) and percentage of responding cells (Fig. 1B) increased in direct proportion to the concentration of agonist applied. Maximal concentrations of either $\mathrm{MCH}$ or PDGF evoked responses in almost all the cells imaged. The latency (time from addition of an agonist to the peak of the $\mathrm{Ca}^{2+}$ signal) declined as the agonist concentration was increased (Fig. 1C). It was evident that the latency was significantly longer over the full dose-response relationship for PDGF in comparison to $\mathrm{MCH}$ (Fig. 1C).

To determine the contributions of $\mathrm{Ca}^{2+}$ release and $\mathrm{Ca}^{2+}$ entry to the responses induced by PDGF and $\mathrm{MCH}$, we examined the effects of the agonists in the presence or absence of extracellular $\mathrm{Ca}^{2+}$ (Fig. 2; concentrations of $\mathrm{MCH}$ and $\mathrm{PDGF}$ giving similar peak $\mathrm{Ca}^{2+}$ signals were used). The initial responses evoked by either agonist were not significantly affected by extracellular $\mathrm{Ca}^{2+}$ (see $\mathrm{Ca}^{2+}$ traces in Fig. $2 \mathrm{~A}$ and $2 \mathrm{C}$ and summarised data the histograms in Fig. 2Bi and Di). However, the extended elevation in cytosolic $\mathrm{Ca}^{2+}$, which occurred when either agonist was applied in the presence of extracellular $\mathrm{Ca}^{2+}$, was abrogated in $\mathrm{Ca}^{2+}$-free conditions (see $\mathrm{Ca}^{2+}$ traces in Fig. 2A and $2 \mathrm{C}$ and summarised data the histograms in Fig. 2Bii and Dii). In the absence of extracellular $\mathrm{Ca}^{2+}$ the cytosolic elevation generally returned to baseline levels within 150 - 200 seconds after initial stimulation $(\mathrm{n}=3$, $\mathrm{p}<0.001$, figs $2 \mathrm{Aii}$ and $\mathrm{Cii}$ ). These data indicate that the intracellular $\mathrm{Ca}^{2+}$ response to PDGF and $\mathrm{MCH}$ consisted of an initial spike, which represented $\mathrm{Ca}^{2+}$ release from intracellular stores and a sustained elevation that depended on extracellular $\mathrm{Ca}^{2+}$. In many cells, the recovery of $\mathrm{Ca}^{2+}$ following stimulation in $\mathrm{Ca}^{2+}$-free media did not follow a simple exponential decline. Rather, there were frequently one or two oscillations of the cytosolic $\mathrm{Ca}^{2+}$ concentration on the declining phase of the response.

Methacholine and PDGF activate a storeoperated $\mathrm{Ca}^{2+}$ entry pathway in NDCs

Having established that $\mathrm{Ca}^{2+}$ influx contributed to the cytosolic $\mathrm{Ca}^{2+}$ transient induced by $\mathrm{PDGF}$ and $\mathrm{MCH}$, we next 

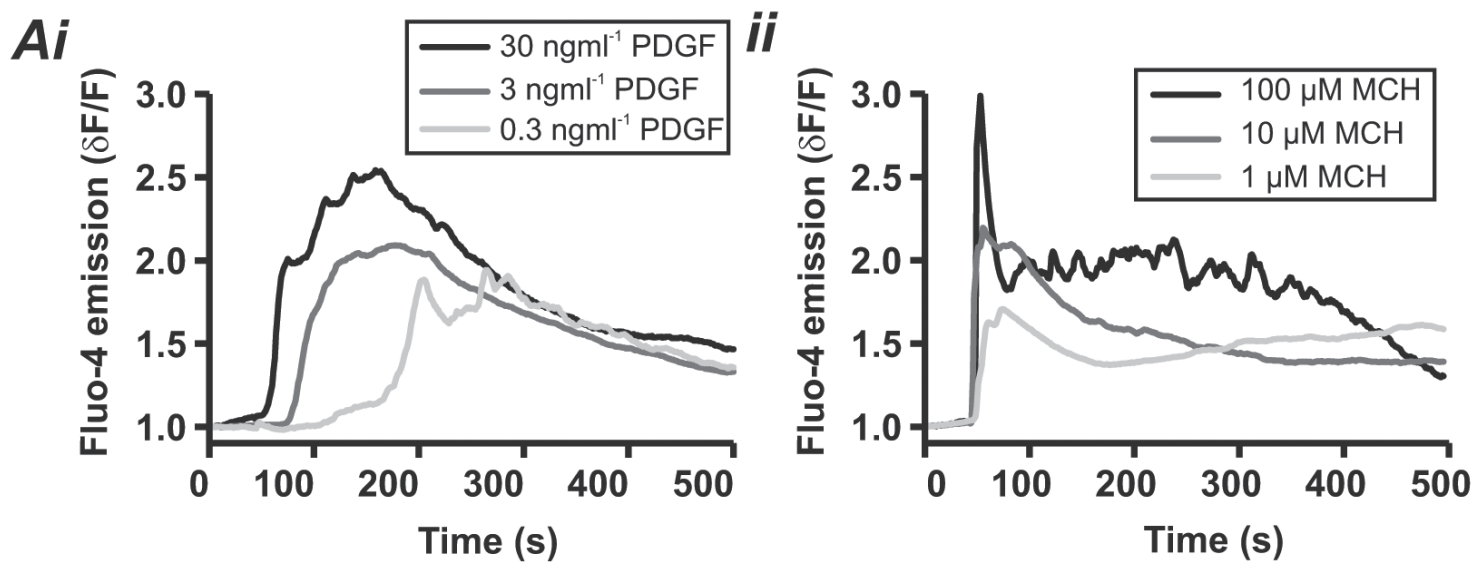

$B i$
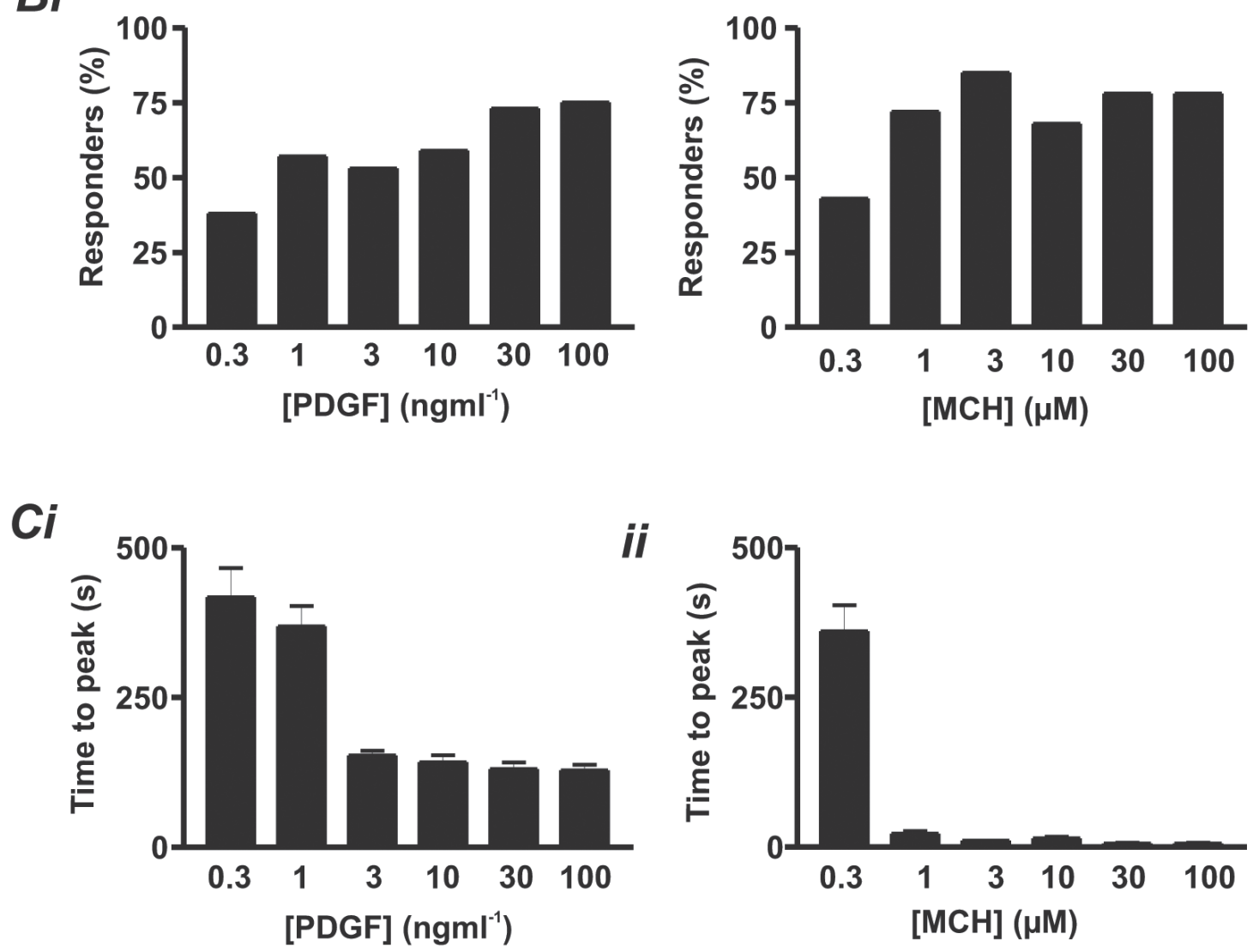

Figure 1: Characterisation of $\mathrm{MCH}-$ and PDGF-induced $\mathrm{Ca}^{2+}$ signals in NDCs. A, Representative traces of the $\mathrm{Ca}^{2+}$ responses induced by the indicated agonist concentrations. B, concentration-dependent effect of $\mathrm{MCH}$ and PDGF on the proportion of responsive cells. A change in fluorescence signal $\left(\Delta \mathrm{F} / \mathrm{F}_{0}\right)>1.1$ was classified as a response. $\mathrm{C}$, averaged data (Mean $\pm \mathrm{SEM}, n$ $>1000$ cells for each condition) indicating the latency (time from agonist addition to the peak of the response) for $\mathrm{MCH}-$ and PDGF-stimulated $\mathrm{Ca}^{2+}$ signals. 

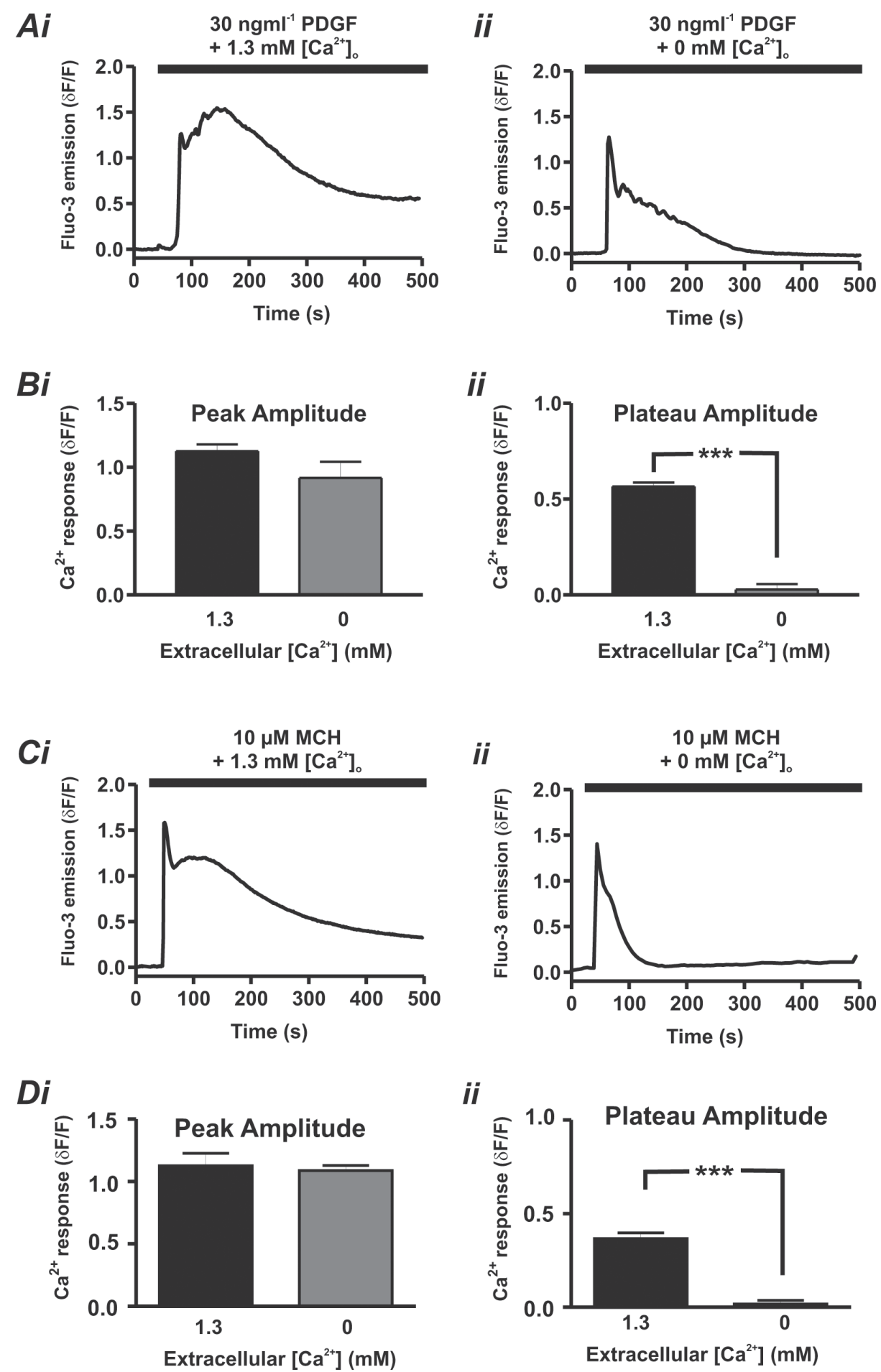

Figure 2: PDGF and $\mathrm{MCH}$ induce $\mathrm{Ca}^{2+}$ release from intracellular stores and $\mathrm{Ca}^{2+}$ influx across the plasma membrane. A and $\mathbf{C}$, representative responses from single NDCs stimulated with the indicated agonist either in (i) $\mathrm{Ca}^{2+}$-containing or (ii) $\mathrm{Ca}^{2+}$-free medium. $\mathbf{B}$ and $\mathbf{D}$, averaged data (Mean \pm SEM, $n>1000$ cells for each condition) summarising: (i) the peak $\mathrm{Ca}^{2+}$ release amplitude (measured $50-100 \mathrm{~s}$ after agonist addition), and (ii) amplitude of the $\mathrm{Ca}^{2+}$ (entry) signal measured at $300 \mathrm{~s}$ post addition of the agonist. *** indicates significance $(\mathrm{p}<0.001)$, and ' $\mathrm{ns}$ ' indicates lack of significant difference. 
investigated the pharmacological profile of the pathway responsible for the entry of $\mathrm{Ca}^{2+}$. In particular, we employed the established $\mathrm{Ca}^{2+}$ entry antagonists SKF96365 and gadolinium $\left(\mathrm{Gd}^{3+}\right)$. The former compound has been used in many studies to probe SOCE (Baba et al., 2003; Flemming et al., 2003; Vostal and Shafer, 1996). Differential sensitivity to high $(100 \mu \mathrm{M})$ or low $(1 \mu \mathrm{M})$ concentration of lanthanides, such as $\mathrm{Gd}^{3+}$, has been used previously to investigate whether $\mathrm{Ca}^{2+}$ entry is arising through a store-operated or non storeoperated $\mathrm{Ca}^{2+}$ entry pathway (Broad et al., 1999).

Experiments were performed to test the relative sensitivities of $\mathrm{PDGF}$ and $\mathrm{MCH}-$ induced $\mathrm{Ca}^{2+}$ entry to $10 \mu \mathrm{M}$ SKF-96365 and $1 \mu \mathrm{M} \mathrm{Gd}^{3+}$. As a positive control, the effect of these inhibitors upon $\mathrm{Ca}^{2+}$ entry induced by thapsigargin was also tested. Thapsigargin is an irreversible inhibitor of the sarcoplasmic endoplasmic reticulum ATPase (SERCA), and it depletes the ER $\mathrm{Ca}^{2+}$ store resulting in robust and specific activation of SOCE (Holmes et al., 2007). To uncover the effect of SKF-96365 and $\mathrm{Gd}^{3+}$ on $\mathrm{Ca}^{2+}$ entry induced by $\mathrm{MCH}$ or PDGF, a protocol was used that involved store depletion by agonist application in the absence of extracellular $\mathrm{Ca}^{2+}$, followed by activation of $\mathrm{Ca}^{2+}$ entry due to re-addition of $\mathrm{Ca}^{2+}$ to the extracellular medium. As shown in figures $3 \mathrm{~A}$ and $\mathrm{B}$, application of either $\mathrm{MCH}$ or PDGF to the cells in $\mathrm{Ca}^{2+}$-free medium evoked an initial rise in intracellular $\mathrm{Ca}^{2+}$, which was due to release from intracellular stores. After this increase in intracellular $\mathrm{Ca}^{2+}$ had returned to baseline levels, $\mathrm{Ca}^{2+}$ was added to the extracellular medium resulting in an elevation in intracellular $\mathrm{Ca}^{2+}$ due to influx across the plasma membrane. Application of $1 \mu \mathrm{M}$ $\mathrm{Gd}^{3+}$ completely abrogated $\mathrm{Ca}^{2+}$ entry induced by both $\mathrm{MCH}$ and PDGF (Figs. 3A and $\mathrm{B})$. This was manifest as a decrease in both the peak $\mathrm{Ca}^{2+}$ signal and integrated $\mathrm{Ca}^{2+}$ transient following $\mathrm{Ca}^{2+}$ re-addition (Figs. 3A and B). No effect of $\mathrm{Gd}^{3+}$ was seen on the $\mathrm{MCH}-$ or PDGF-induced $\mathrm{Ca}^{2+}$ release. $\mathrm{Gd}^{3+}$ exhibited a similarly complete degree of inhibition upon $\mathrm{Ca}^{2+}$ influx following store depletion with thapsigargin (Fig. 3C).
SKF-96365 also significantly reduced the $\mathrm{Ca}^{2+}$ entry signal induced by both $\mathrm{MCH}$ and PDGF, without affecting $\mathrm{Ca}^{2+}$ release (Figs. $3 \mathrm{~A}$ and $\mathrm{B})$. The degree of inhibition of PDGF- and $\mathrm{MCH}$-induced $\mathrm{Ca}^{2+}$ entry by SKF-96365 was not as great as that observed for $\mathrm{Gd}^{3+}$ (Fig. 3A and B). The reduced efficacy of SKF-96365, compared to $\mathrm{Gd}^{3+}$, in inhibiting $\mathrm{Ca}^{2+}$ influx induced by $\mathrm{MCH}$ and PDGF was also mirrored by its lower potency in inhibiting thapsigargin-induced $\mathrm{Ca}^{2+}$ entry (Fig. 3C). These data indicate that $\mathrm{Ca}^{2+}$ signals induced by $\mathrm{MCH}, \mathrm{PDGF}-$ and thapsigargin were similarly affected by $\mathrm{Gd}^{3+}$ and SKF-96365.

We also tested the possibility that $\mathrm{MCH}$ or PDGF could activate alternative, nonSOCE, $\mathrm{Ca}^{2+}$ entry pathways. This was examined by applying $\mathrm{MCH}$ or PDGF to cells during an on-going SOCE signal that had been activated by thapsigargin (Fig. 4). As a positive control, we also utilised calmidazolium (CMZ), which we have previously demonstrated to activate a nonSOCE pathway (Holmes et al., 2007; Peppiatt et al., 2004). Cells were treated with thapsigargin for 20 minutes to completely discharge the ER and activate SOCE. Subsequently, MCH, PDGF or calmidazolium were added. Of these agents, only calmidazolium triggered an additional $\mathrm{Ca}^{2+}$ influx. The similarity of the pharmacological profiles of both $\mathrm{MCH}-$, PDGF- or thapsigargin-induced $\mathrm{Ca}^{2+}$ influx, and the inability of $\mathrm{MCH}$ or PDGF to induce further $\mathrm{Ca}^{2+}$ entry after thapsigarginmediated SOCE activation, suggests that a common $\mathrm{Ca}^{2+}$ entry mechanism is activated by all three agents.

\section{MCH-activated SOCE is dependent upon TRPC6 expression}

TRP channels have been suggested to underlie store-operated $\mathrm{Ca}^{2+}$ entry in a number of cell types, and play important roles in neuronal physiology. Microarray analysis of our NDCs revealed that mRNAs for TRPC5 and TRPC6 were abundant (data not shown). We considered the possibility that TRPC5 might underlie the $\mathrm{Ca}^{2+}$ entry signals that we see. However, TRPC5 has been shown to negatively regulate neuronal 
$\mathbf{A i}$

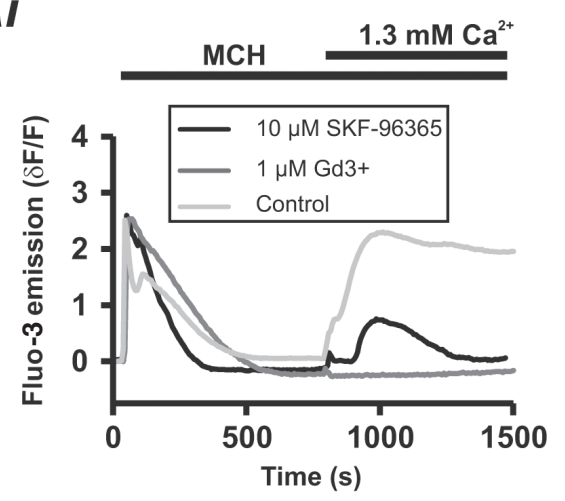

Bi
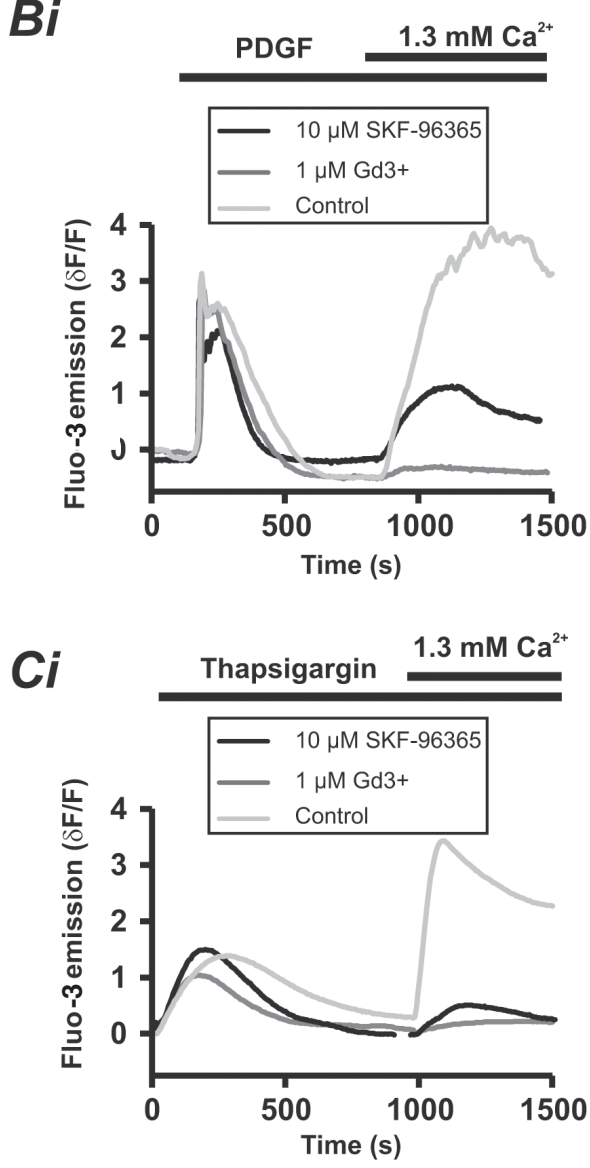

ii

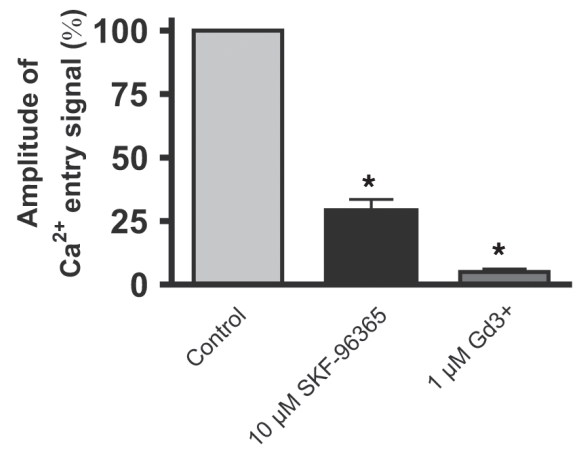

ii

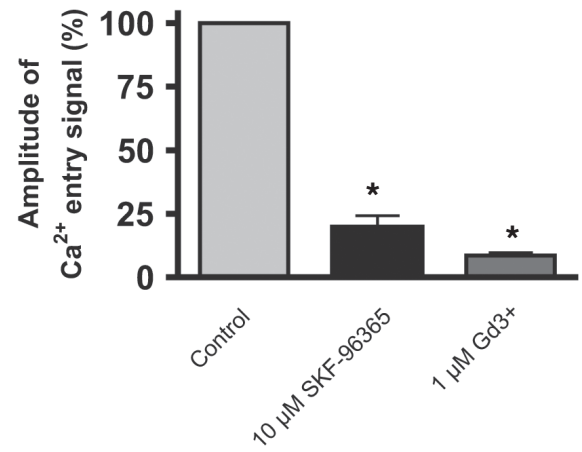

ii

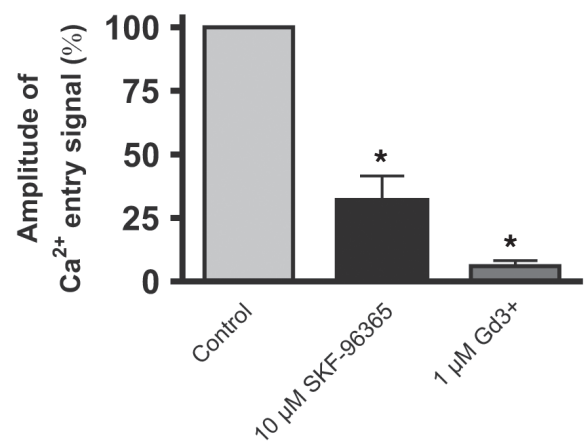

Figure 3: PDGF- and $\mathrm{MCH}$-stimulated $\mathrm{Ca}^{2+}$ entry is pharmacologically similar to thapsigargin-activated SOCE. $\mathrm{Ca}^{2+}$ influx in response to cellular stimulation with $\mathrm{MCH}$, PDGF and Thapsigargin was imaged in NDCs. Following depletion of the intracellular $\mathrm{Ca}^{2+}$ store, extracellular $\mathrm{Ca}^{2+}(1.3 \mathrm{mM})$ was added back to the cells in the presence or absence of $\mathrm{Gd}^{3+}(1 \mu \mathrm{M})$ or SKF-96365 $(10 \mu \mathrm{M})$. Ai $-\mathbf{C i}$, representative traces showing responses to MCH, PDGF and thapsigargin, in the presence or absence of the $\mathrm{Ca}^{2+}$ entry inhibitors. Aii - Cii, averaged data (Mean \pm SEM, $n>1000$ cells for each condition) indicating the integrated $\mathrm{Ca}^{2+}$ signal (i.e. area under the $\mathrm{Ca}^{2+}$ trace) measured for 10 minutes following readdition of extracellular $\mathrm{Ca}^{2+}$.* indicates statistically significance $(\mathrm{p}<0.05)$. 


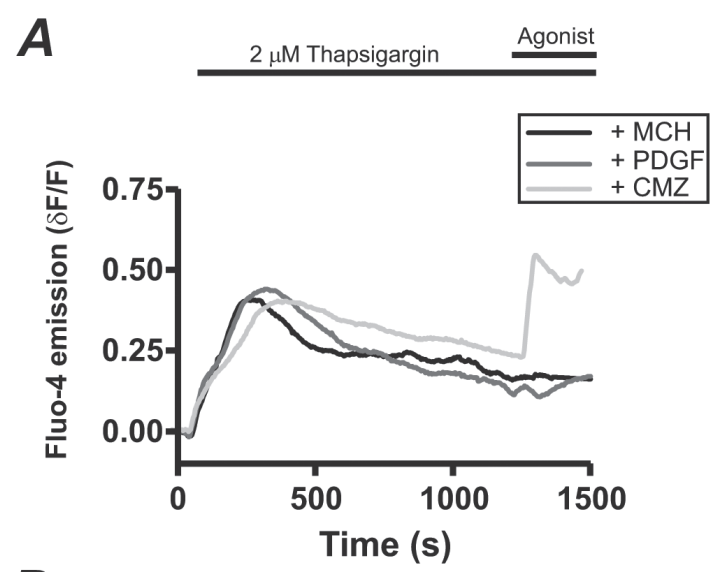

B

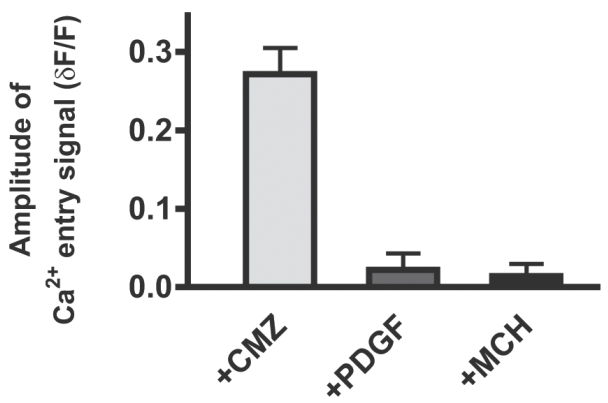

Figure 4: The $\mathrm{Ca}^{2+}$ influx stimulated by PDGF or MECH is not additive with thapsigargin-activated SOCE. A, representative traces showing the lack of effect of PDGF $(30 \mathrm{ng} / \mathrm{ml})$ or $\mathrm{MCH}(10 \mu \mathrm{M})$ during an on-going thapsigargin-evoked SOCE signal. Calmidazolium $(10 \mu \mathrm{M})$ was used as a positive control, and did induce additional $\mathrm{Ca}^{2+}$ influx. B, averaged data (Mean \pm SEM, $n>100$ cells for each condition) indicating the net effect of calmodazolium, PDGF or $\mathrm{MCH}$ to the thapsigargin-evoked SOCE response.

outgrowth (Greka et al., 2003), but $\mathrm{Ca}^{2+}$ entry potentiates neurite outgrowth in our NDCs (unpublished observations). Furthermore, TRPC5 activity is potentiated by lanthanides (Clapham et al., 2001), whereas we observed an inhibition of $\mathrm{Ca}^{2+}$ entry by $\mathrm{Gd}^{3+}$. For these reasons, TRPC5 was not considered further during this study. TRPC6 appeared an attractive candidate as it has previously been implicated in mediating SOCE in other cell types (Yuan et al., 2003).

The role of TRPC6 in PDGF-, Thapsigargin- and $\mathrm{MCH}$-induced $\mathrm{Ca}^{2+}$ entry into NDCs was examined by exploiting specifically-targeted siRNAs to reduce protein expression. NDCs were transfected with pooled siRNAs designed against four regions of TRPC6 mRNA for 24 hours, after which TRPC6 expression was investigated by immunoblotting (figure 5A). Parallel experiments using a fluorescent, Cy3conjugated siRNA indicated that greater than 90\% transfection efficiency was achieved using the transfection protocol (Fig. 5B). Endogenous TRPC6 in mouse brain lysates, and in lysates prepared from the untreated control NDCs was detected as two bands. These two bands are proposed to represent endogenous TRPC6 $(\sim 106 \mathrm{kDa})$ and a splice variant $(\sim 50 \mathrm{kDa})$. Following 24 hours TRPC6 siRNA transfection, TRPC6 protein levels were substantially reduced (the 106 $\mathrm{kD}$ band by $66 \%$, and the $50 \mathrm{kD}$ band by $50 \%)$.

For $\mathrm{Ca}^{2+}$ imaging experiments, NDCs were transfected with TRPC6 siRNA 24 hours prior to experimentation. Cy3conjugated, luciferase-directed siRNAs were used for control. TRPC6 siRNA and Cy3-conjugated siRNA transfected cells were stimulated with $\mathrm{MCH}(10 \mu \mathrm{M})$, thapsigargin $(2 \mu \mathrm{M})$, or PDGF $(30 \mathrm{ng} / \mathrm{ml})$ in the absence of extracellular $\mathrm{Ca}^{2+}$ to deplete the intracellular $\mathrm{Ca}^{2+}$ store. SOCE was subsequently initiated by addition of $\mathrm{Ca}^{2+}$ to the extracellular buffer (Fig. 5CiEi). TRPC6 reduction had no effect upon the amplitude of the initial $\mathrm{Ca}^{2+}$ transients arising through release from intracellular $\mathrm{Ca}^{2+}$ stores. However, TRPC6 siRNA transfection had different effects upon SOCE induced by PDGF, $\mathrm{MCH}$ or thapsigargin. Specifically, $\mathrm{MCH}$-induced $\mathrm{Ca}^{2+}$ entry was significantly reduced in cells transfected with TRPC6 siRNA when compared with control-transfected cells (Fig. 5Cii). Whereas, TRPC6 reduction did not affect thapsigargin- or PDGF-induced $\mathrm{Ca}^{2+}$ influx (Figure 5Dii and Eii).

\section{DISCUSSION}

It has been demonstrated that $\mathrm{Ca}^{2+}$ signals play a key role in neuronal development controlling differentiation, neurite 

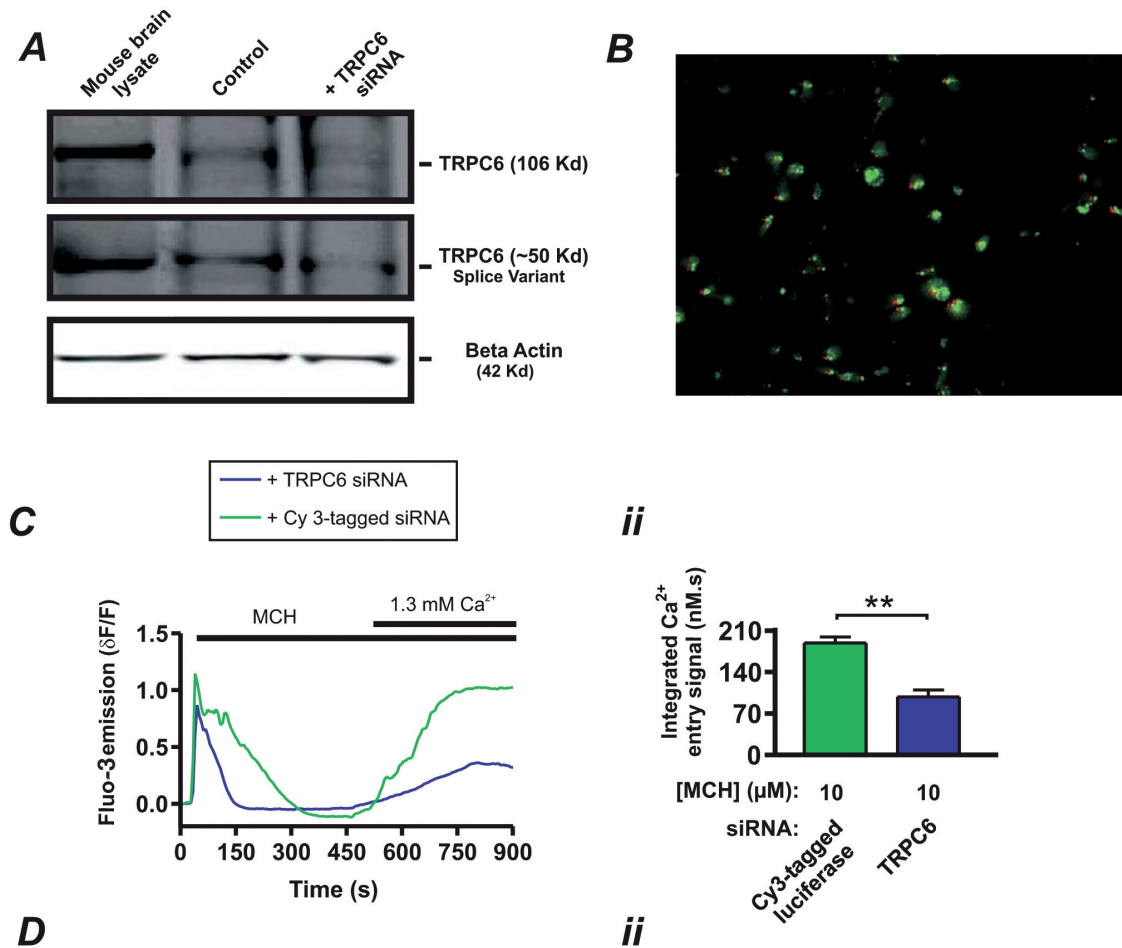

D

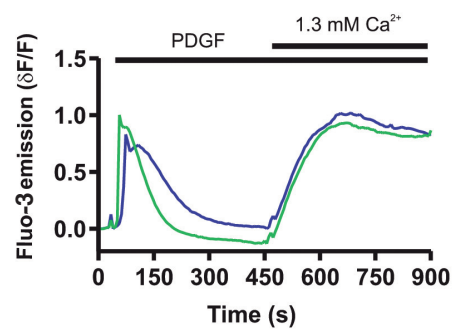

ii

$E$
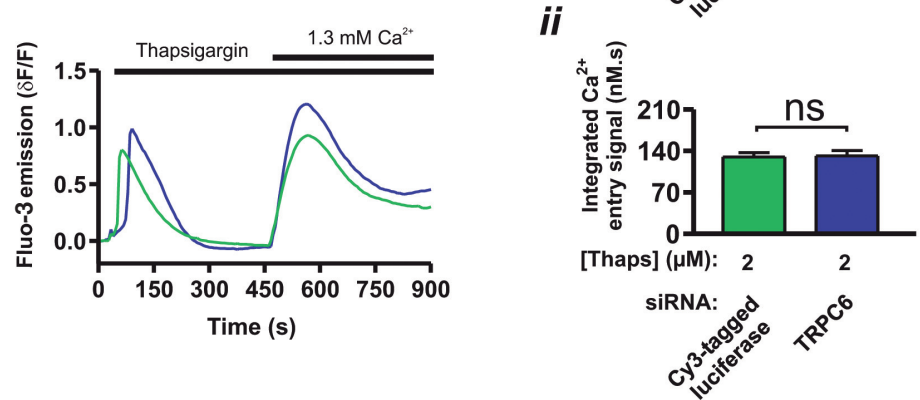

Figure 5: TRPC6 is a component of $\mathrm{MCH}$-induced $\mathrm{Ca}^{2+}$ entry. A, upper panels, immunoblots showing the abundance of the $105 \mathrm{kDA}$ and $50 \mathrm{kDa}$ splice variants of TRPC6 in mouse brain lysate, and in lysates prepared from NDCs $24 \mathrm{~h}$ post-transfection with control Cy3-conjugated luciferase siRNA or TRPC6 siRNA. Lower panel, immunoblot showing the abundance of $\beta$-actin (used as a loading control) in the lysates described above. B, Representative overlay image of cells loaled with calcein (marker of cell viability, green) and Cy3-tagged luciferase siRNA (control siRNA, red). Ci - Ei, typical traces showing $\mathrm{MCH}-$, PDGF- and thapsigargin-induced $\mathrm{Ca}^{2+}$ influx in NDCs 24 hours post transfection with TRPC6 siRNA or control Cy3-conjugated luciferase siRNA. Data is shown as mean \pm SEM ( $n>500$ cells). Cii - Eii, averaged data (Mean \pm SEM, $n>1000$ cells for each condition) indicating the integrated $\mathrm{Ca}^{2+}$ signal (i.e. area under the $\mathrm{Ca}^{2+}$ trace) measured for 8 minutes following readdition of extracellular $\mathrm{Ca}^{2+}$. $*$ indicates statistically significance $(\mathrm{p}<0.01)$. 
outgrowth and pathfinding (Bezzerides et al., 2004; Shim et al., 2005). Indeed, we have previously shown that PDGF induces neurite outgrowth in NDCs in a $\mathrm{Ca}^{2+}$ dependent manner (Richards et al., 2006). Stimulation of muscarinic receptors, on the other hand, promotes NDC proliferation without neurite outgrowth (unpublished observations). An aim of this study was to examine whether the differing biological outcomes (i.e. neurite outgrowth versus proliferation) caused by PDGF and muscarinic receptor stimulation was due to alternative patterns of $\mathrm{Ca}^{2+}$ signalling.

$\mathrm{Ca}^{2+}$ transients elicited by both agonists were comprised of $\mathrm{Ca}^{2+}$ release from finite intracellular stores, followed by a prolonged elevated level of intracellular $\mathrm{Ca}^{2+}$, which was due to $\mathrm{Ca}^{2+}$ flux across the plasma membrane (Figs. 1 and 2). The pattern of $\mathrm{Ca}^{2+}$ signals evoked by PDGF and $\mathrm{MCH}$ in NDCs is typical of the response of many different cell types to Ins $\mathrm{P}_{3}$-generating agonists (Bootman et al., 1992; Trebak et al., 2002b). $\mathrm{Ca}^{2+}$ entry induced by both PDGF and $\mathrm{MCH}$ was pharmacologically similar to the SOCE pathway initiated by $\mathrm{ER} \mathrm{Ca}^{2+}$ store depletion with thapsigargin (Fig. 3).

Although the amplitudes of the $\mathrm{Ca}^{2+}$ transients induced by either $\mathrm{MCH}$ or PDGF were similar at maximal concentrations, the time taken to reach the peak of the $\mathrm{Ca}^{2+}$ transient was typically greater for PDGF than $\mathrm{MCH}$ (Fig. 1). This increased latency became more pronounced with decreasing agonist concentrations. These differences can in part be ascribed to the different kinetics of $\mathrm{InsP}_{3}$ generation downstream of PDGFR and mAChR activation. Stimulation by PDGF results in dimerisation of plasma membrane-localised receptors and phosphorylation of serine and tyrosine residues, which leads to downstream activation of PLC $\gamma$ (Clapham, 1995). A recent study presented evidence for a lipase-independent role for PLC $\gamma$ in the activation of $\mathrm{Ca}^{2+}$ entry (Patterson et al., 2002), suggesting that rather than $\mathrm{Ca}^{2+}$ release from intracellular stores driving $\mathrm{Ca}^{2+}$ entry, PDGFRs could couple directly to $\mathrm{Ca}^{2+}$ entry channels with which they colocalise in signalling microdomains
(Ambudkar et al., 2004). Although our data cannot rule out such a mechanism for PDGF-evoked $\mathrm{Ca}^{2+}$ entry, we did not observe any additional $\mathrm{Ca}^{2+}$ influx when PDGF was applied to NDCs with an ongoing SOCE response (Fig. 4). This would suggest that any store-independent $\mathrm{Ca}^{2+}$ entry activated by PDGF is less profound than SOCE.

In this study, PDGF and $\mathrm{MCH}$ were both found to activate SOCE. This conclusion was based upon the findings that they released $\mathrm{Ca}^{2+}$ from intracellular stores, and that the $\mathrm{Ca}^{2+}$ entry stimulated by both agonists was sensitive to $\mathrm{Gd}^{3+}$ and SKF96365, which are known inhibitors of SOCE. The degree of inhibition of $\mathrm{MCH}-$ and PDGF-evoked $\mathrm{Ca}^{2+}$ influx by $\mathrm{Gd}^{3+}$ and SKF-96365 was similar to the reduction of SOCE when it was induced by thapsigargin. The incomplete inhibition of $\mathrm{Ca}^{2+}$ entry by SKF-96365 is typical of its effects seen in other systems (Merritt et al., 1990; Vassilopoulos et al., 2007). Although the $\mathrm{Ca}^{2+}$ entry pathways activated by PDGF, $\mathrm{MCH}$ and thapsigargin were pharmacologically indistinguishable from each other, we detected a differential sensitivity to reduction of TRPC6 (Fig. 5). siRNA-mediated knockdown of TRPC6 resulted in a profound decrease in the magnitude of $\mathrm{MCH}$-induced $\mathrm{Ca}^{2+}$ entry. No effect on $\mathrm{Ca}^{2+}$ entry induced by PDGF or thapsigargin was however seen. Although TRPC6 was initially characterised as a DAG-activated cation channel (Hofmann et al., 1999), other reports suggest that it may mediate SOCE (Singh et al., 2007; Yu et al., 2003). In certain cellular contexts, TRPC 3 and 7, other members of the TRPC subclass to which TRPC6 belongs, have also been reported to form store-operated channels. For example, when expressed at low levels, TRPC3 and 7, form channels that are store-operated, whereas when highly overexpressed they form channels that are non-store operated (Lievremont et al., 2004; Trebak et al., 2002a).

Given that $\mathrm{Ca}^{2+}$ is a profound regulator of neuronal behaviour, the channels that underlie its movement represent attractive targets for therapeutic intervention. We have previously found that stimulation of 
NDCs with PDGF or $\mathrm{MCH}$ results in different biological outcomes. In our hands, the former agonist promotes NDC proliferation neurite outgrowth, whilst the latter stimulates proliferation but not neurite extension. It is likely that $\mathrm{Ca}^{2+}$ is a key signal in both of these activities. At a gross level, the $\mathrm{Ca}^{2+}$ signals evoked by $\mathrm{MCH}$ and PDGF are very similar. However, probing the molecular nature of the pathways responsible for $\mathrm{Ca}^{2+}$ influx reveals that $\mathrm{MCH}$ and $\mathrm{PDGF}$ do not employ the same channels. It is therefore possible that subtle differences in the spatial distribution of the $\mathrm{Ca}^{2+}$ channels recruited by $\mathrm{MCH}$ or PDGF, along with the engagement of other signalling elements, allow these two agonists to produce distinctive biological effects.

\section{REFERENCES}

ÁLVAREZ-BUYLlA, A and TEMPLE, S (1998) Stem cells in the developing and adult nervous system. $J$ Neurobiol 36: 105-10

AMBUDKAR, IS, BRAZER, SC, LIU, X, LOCKWICH, T and SINGH, B (2004) Plasma membrane localization of TRPC channels: role of caveolar lipid rafts Novartis Found Symp 258: 63-70; discussion 70-4: 98-102: 263-6

ARMSTRONG, RJ and SVENDSEN, CN (2000) Neural stem cells: from cell biology to cell replacement. Cell Transplant 9: 139-52

BABA, A, YASUI, T, FUJISAWA, S, YAMADA, RX, YAMADA, MK, NISHIYAMA, N, MATSUKI, N and IKEGAYA, Y (2003) Activity-evoked capacitative $\mathrm{Ca} 2+$ entry: implications in synaptic plasticity. $J$ Neurosci 23: 7737-41

BERRIDGE, M J (1997) Elementary and global aspects of calcium signalling. J Exp Biol 200 (Pt 2), 315-9

BERRIDGE, MJ (1998) Neuronal calcium signaling. Neuron 21: 13-26

BERRIDGE, MJ, BOOTMAN, MD and RODERICK, HL (2003) Calcium signalling: dynamics, homeostasis and remodelling. Nat Rev Mol Cell Biol 4: 517-29

BEZZERIDES, VJ, RAMSEY, IS, KOTECHA, S, GREKA, A and CLAPHAM, DE (2004) Rapid vesicular translocation and insertion of TRP channels. Nat Cell Biol 6: 709-20

BOOTMAN, MD, BERRIDGE, MJ and TAYLOR, CW (1992) All-or-nothing Ca2+ mobilization from the intracellular stores of single histamine-stimulated HeLa cells. J Physiol 450: 163-78

BROAD, LM, CANNON, TR and TAYLOR, CW (1999) A non-capacitative pathway activated by arachidonic acid is the major $\mathrm{Ca} 2+$ entry mechanism in rat $\mathrm{A} 7 \mathrm{r} 5$ smooth muscle cells stimulated with low concentrations of vasopressin. J Physiol 517 (Pt 1), 121-34

CALDWELL, MA, HE, X, WILKIE, N, POLLACK, S, MARSHALL, G, WAFFORD, KA and SVENDSEN, C N (2001) Growth factors regulate the survival and fate of cells derived from human neurospheres. Nat Biotechnol 19: 475-9
CAMERON, HA and MCKAY, R (1998) Stem cells and neurogenesis in the adult brain. Curr Opin Neurobiol 8: $677-80$

CAULFIELD, MP (1993) Muscarinic receptorscharacterization, coupling and function. Pharmacol Ther 58: 319-79

CHYB, S, RAGHU, P and HARDIE, RC (1999) Polyunsaturated fatty acids activate the Drosophila light-sensitive channels TRP and TRPL. Nature 397: 255-9

CLAPHAM, DE (1995) Calcium signaling. Cell 80: 25968

CLAPHAM, DE, RUNNELS, LW and STRUBING, C (2001) The TRP ion channel family. Nat Rev Neurosci 2: $387-96$

DELMAS, P, WANAVERBECQ, N, ABOGADIE, FC, MISTRY, $M$ and BROWN, DA (2002) Signaling microdomains define the specificity of receptormediated InsP(3) pathways in neurons. Neuron 34: 209-220

DOETSCH, F, PETREANU, L, CAILLE, I, GARCIAVERDUGO, JM and ALVAREZ-BUYLLA, A (2002) EGF converts transit-amplifying neurogenic precursors in the adult brain into multipotent stem cells. Neuron 36: $1021-34$

DUNNETT, SB, BJORKLUND, A and LINDVALL, O (2001) Cell therapy in Parkinson's disease - stop or go? Nat Rev Neurosci 2: 365-9

ERLANDSSON, A, ENARSSON, $\mathrm{M}$ and FORSBERGNILSSON, K (2001) Immature neurons from CNS stem cells proliferate in response to platelet-derived growth factor. J Neurosci 21: 3483-91

FLEMMING, R, XU, SZ and BEECH, DJ (2003) Pharmacological profile of store-operated channels in cerebral arteriolar smooth muscle cells. $\mathrm{Br} J$ Pharmacol 139: 955-65

GAGE, FH (1998) Stem cells of the central nervous system. Curr Opin Neurobiol 8: 671-6

GREKA, A, NAVARRO, B, OANCEA, E, DUGGAN, A and CLAPHAM, D E (2003) TRPC5 is a regulator of hippocampal neurite length and growth cone morphology. Nat Neurosci 6: 837-45

HOFMANN, T, OBUKHOV, AG, SCHAEFER, M, HARTENECK, C, GUDERMANN, T and SCHULTZ, G (1999) Direct activation of human TRPC6 and TRPC3 channels by diacylglycerol. Nature 397: 259-63

HOLMES, AM, RODERICK, HL, MCDONALD, F and BOOTMAN, MD (2007) Interaction between storeoperated and arachidonate-activated calcium entry. Cell Calcium 41: 1-12

KASRI, NN, HOLMES, AM, BULTYNCK, G, PARYS, J B, BOOTMAN, MD, RIETDORF, K, MISSIAEN, L, MCDONALD, F, DE SMEDT, H, CONWAY, SJ et al. (2004) Regulation of InsP3 receptor activity by neuronal Ca2+-binding proteins. Embo $J$ 23: 312-21

LEZCANO, N and BERGSON, C (2002) D1/D5 dopamine receptors stimulate intracellular calcium release in primary cultures of neocortical and hippocampal neurons. J Neurophysiol 87: 2167-75

LIEVREMONT, JP, BIRD, GS and PUTNEY, JW, Jr (2004) Canonical transient receptor potential TRPC7 can function as both a receptor- and store-operated channel in HEK-293 cells. Am J Physiol Cell Physiol 287: C1709-16

MA, W, MARIC, D, LI, BS, HU, Q, ANDREADIS, JD, GRANT, GM, LIU, QY, SHAFFER, KM, CHANG, YH, ZHANG, L et al. (2000) Acetylcholine stimulates cortical precursor cell proliferation in vitro via muscarinic receptor activation and MAP kinase phosphorylation. Eur J Neurosci 12: 1227-40 
MCKAY, R (2000) Stem cells and the cellular organization of the brain. J Neurosci Res 59: 298-300

MERRITT, JE, ARMSTRONG, WP, BENHAM, CD, HALLAM, TJ, JACOB, R, JAXA-CHAMIEC, A, LEIGH, BK, MCCARTHY, SA, MOORES, KE and RINK, TJ (1990) SK\&F 96365, a novel inhibitor of receptor-mediated calcium entry. Biochem J 271: 51522

MONEER, Z and TAYLOR, CW (2002) Reciprocal regulation of capacitative and non-capacitative $\mathrm{Ca} 2+$ entry in A7r5 vascular smooth muscle cells: only the latter operates during receptor activation. Biochem $J$ 362: $13-21$

PAREKH, AB and PUTNEY, JW, Jr. (2005) Store-operated calcium channels. Physiol Rev 85: 757-810

PATTERSON, RL, VAN ROSSUM, DB, FORD, DL, HURT, KJ, BAE, SS, SUH, PG, KUROSAKI, T, SNYDER, S H and GILL, D L (2002) Phospholipase $\mathrm{C}$-gamma is required for agonist-induced $\mathrm{Ca} 2+$ entry. Cell 111: 529-41

PEPPIATT, CM, HOLMES, AM, SEO, JT, BOOTMAN, MD, COLLINS, TJ, MCDONALD, F and RODERICK, HL (2004) Calmidazolium and arachidonate activate a calcium entry pathway that is distinct from storeoperated calcium influx in HeLa cells. Biochem J 381: 929-39

PUTNEY, JW, Jr. (1986) A model for receptor-regulated calcium entry. Cell Calcium 7: 1-12

REYNOLDS, BA and WEISS, S (1992) Generation of neurons and astrocytes from isolated cells of the adult mammalian central nervous system. Science 255: 170710

RICHARDS, GR, MILLARD, RM, LEVERIDGE, M, KERBY, J and SIMPSON, PB (2004) Quantitative assays of chemotaxis and chemokinesis for human neural cells. Assay Drug Dev Technol 2: 465-72

RICHARDS, GR, SMITH, A J, CUDDON, P, MA, QP, LEVERIDGE, M, KERBY, J, RODERICK, HL, BOOTMAN, MD and SIMPSON, PB (2006) The JAK3 inhibitor WHI-P154 prevents PDGF-evoked process outgrowth in human neural precursor cells. $J$ Neurochem 97: 201-10

RIDET, JL, MALHOTRA, SK, PRIVAT, A and GAGE, F H (1997) Reactive astrocytes: cellular and molecular cues to biological function. Trends Neurosci 20: 570-7

SHIM, S, GOH, EL, GE, S, SAILOR, K, YUAN, JP, RODERICK, HL, BOOTMAN, MD, WORLEY, PF, SONG, H and MING, GL (2005) XTRPC1-dependent chemotropic guidance of neuronal growth cones. Nat Neurosci 8: 730-5

SHUTTLEWORTH, TJ and THOMPSON, JL (1999) Discriminating between capacitative and arachidonateactivated $\mathrm{Ca}(2+)$ entry pathways in HEK293 cells. $J$ Biol Chem 274: 31174-8

SIMPSON, PB, CHALLISS, RA and NAHORSKI, SR (1994) Chronic activation of muscarinic and metabotropic glutamate receptors down-regulates type I inositol 1,4,5-trisphosphate receptor expression in cerebellar granule cells. J Neurochem 63: 2369-72

SINGH, I, KNEZEVIC, N, AHMMED, GU, KINI, V, MALIK, AB and MEHTA, D (2007) Galphaq-TRPC6- mediated $\mathrm{Ca} 2+$ entry induces RhoA activation and resultant endothelial cell shape change in response to thrombin. J Biol Chem 282: 7833-43

SPITZER, NC (2002) Activity-dependent neuronal differentiation prior to synapse formation: the functions of calcium transients $J$ Physiol Paris 96: 7380

SPRADLING, A, DRUMMOND-BARBOSA, D and KAI, T (2001) Stem cells find their niche. Nature 414: 98104

SVENDSEN, CN, BHATTACHARYYA, A and TAI, YT (2001) Neurons from stem cells: preventing an identity crisis Nat Rev Neurosci 2: 831-4

SVENDSEN, CN, TER BORG, MG, ARMSTRONG, RJ, ROSSER, AE, CHANDRAN, S, OSTENFELD, T and CALDWELL, MA (1998) A new method for the rapid and long term growth of human neural precursor cells. J Neurosci Methods 85: 141-52

TREBAK, M, BIRD, GS, MCKAY, RR and PUTNEY, JW, Jr. (2002a) Comparison of human TRPC3 channels in receptor-activated and store-operated modes. Differential sensitivity to channel blockers suggests fundamental differences in channel composition. J Biol Chem 277: 21617-23

TREBAK, M, ST, JBG, MCKAY, RR and PUTNEY, JW, Jr. (2002b) Comparison of Human TRPC3 Channels in Receptor-activated and Store-operated Modes. Differential sensitivity to channel blockers suggests fundamental differences in channel composition. J Biol Chem 277: 21617-21623

VASSILOPOULOS, S, BROCARD, J, GARCÍA, L, MARTY, I and BOURON, A (2007) Retrograde regulation of store-operated calcium channels by the ryanodine receptor-associated protein triadin 95 in rat skeletal myotubes. Cell Calcium 41: 179-85

VOSTAL, JG and SHAFER, B (1996) Thapsigargininduced calcium influx in the absence of detectable tyrosine phosphorylation in human platelets. J Biol Chem 271: 19524-9

YAMAMOTO, K, HASHIMOTO, K, NAKANO, M, SHIMOHAMA, S and KATO, N (2002) A distinct form of calcium release down-regulates membrane excitability in neocortical pyramidal cells. Neuroscience 109: 665-676

YU, Y, SWEENEY, M, ZHANG, S, PLATOSHYN, O, LANDSBERG, J, ROTHMAN, A and YUAN, JX (2003) PDGF stimulates pulmonary vascular smooth muscle cell proliferation by upregulating TRPC6 expression. Am J Physiol Cell Physiol 284: C316-30

YUAN, JP, KISELYOV, K, SHIN, DM, CHEN, J, SHCHEYNIKOV, N, KANG, SH, DEHOFF, MH, SCHWARZ, MK, SEEBURG, PH, MUALLEM, S et al. (2003) Homer binds TRPC family channels and is required for gating of TRPC1 by IP 3 receptors. Cell 114: 777-89

ZHAO, WQ, ALKON, DL and MA, W (2003) c-Src protein tyrosine kinase activity is required for muscarinic receptor-mediated DNA synthesis and neurogenesis via ERK $1 / 2$ and c-AMP-responsive element-binding protein signaling in neural precursor cells. J Neurosci Res 72: 334-42 
